\title{
Subcutaneous photophores in the jumbo squid Dosidicus gigas (d'Orbigny, 1835) (Cephalopoda: Ommastrephidae)
}

\author{
Fotóforos subcutáneos en el calamar gigante Dosidicus gigas (d'Orbigny, 1835) \\ (Cephalopoda: Ommastrephidae) \\ Karin B. Lohrmann ${ }^{1}$
}

${ }^{1}$ Facultad de Ciencias del Mar, Universidad Católica del Norte, Coquimbo, Chile. Larrondo 1281, Coquimbo, Chile klohrman@ucn.cl

\begin{abstract}
Resumen.- En Dosidicus gigas se observaron pequeñas inclusiones de color amarillo pálido embebidas a distintas profundidades en el músculo del manto, las que corresponden a fotóforos. A nivel histológico los fotóforos están formados por un tejido fotogenerador, que se tiñe de color naranja intenso con tinción tricrómica de Mallory y un tejido vacuolar, que lo rodea y penetra en éste, con numerosos vasos sanguíneos. Ultraestructuralmente, el tejido fotogenerador es denso a los electrones, homogéneo y finamente granular. Los fotóforos subcutáneos se observaron en todo el calamar, en cabeza, manto, aletas, brazos y tentáculos, por dorsal y ventral. En brazos y tentáculos se observaron escasos fotóforos ubicados a lo largo, tanto del nervio axial, como del borde externo, excepto en el cuarto par de brazos, en que los fotóforos, presentes en las mismas ubicaciones, son mucho más numerosos, formando una hilera casi continua. En trozos de manto fresco o congeladodescongelado se observó una luminiscencia amarillo-verdosa en un cuarto oscuro. Los fotóforos de D. gigas tienen una estructura muy similar a la de Sthenoteuthis pteropus. La única diferencia es que esta última especie tiene una cápsula de tejido conectivo alrededor del fotóforo, ausente en D. gigas. La estructura del fotóforo de D. gigas es muy básica, y probablemente sea la más simple dentro de la subfamilia Ommastrephinae.
\end{abstract}

Palabras clave: inclusiones amarillas, histología, ultraestructura

\section{Introduction}

The jumbo squid, Dosidicus gigas (d'Orbigny, 1835), is a nektonic cephalopod, which inhabits the eastern Pacific (Roper et al. 1984), and periodically approaches the Chilean coast, including Coquimbo. Its biomass peaked in 1991-92, dropping in 1994, until disappearing in 1995 (Schmiede \& Acuña 1992, Fernández \& Vásquez 1995). It appeared again in 2001 with a total catch of 3,476 tons rising up to 250,989 tons in 2006 (Sernapesca 2001 ${ }^{1}$,

\footnotetext{
${ }^{1}$ Sernapesca, 2001. Servicio Nacional de Pesca, Anuario Estadístico. Ministerio de Economía, Fomento y Reconstrucción, Chile. (http://www.sernapesca.cl) [consultado el 5 de mayo, 2008].
}

\begin{abstract}
In Dosidicus gigas small pale yellow ovoid inclusion bodies corresponded to subcutaneous photophores, which were embedded in the mantle muscle, at differing depths. At the histological level the photophores were composed of a photogenic tissue, which stained bright orange with Mallory triple stain. Surrounding it was a vacuolated tissue with numerous blood vessels which also intruded into the lightemitting tissue. Viewed with transmission electron microscopy the photogenic tissue was electron dense and homogeneously finely granular, in close contact with capillaries of the intruding vacuolar connective tissue. Subcutaneous photophores were observed over the whole squid on tentacles, arms, head, mantle and the fins, both dorsally and ventrally. On arms and tentacles the photophores were sparsely located along the axial nerve, and along the outer edge, with the exception of the fourth pair of arms, where the photophores, having the same location, were very numerous, forming an almost continuous row. A yellowgreenish luminescence could be observed on fresh or frozenthawed muscle in a dark room. The subcutaneous light organs of $D$. gigas have a very similar structure to those described for Sthenoteuthis pteropus. The only difference with S. pteropus is that this latter species has an additional connective tissue capsule around the phototophore. The structure of the photophore of D. gigas is very basic, and is probably the simplest one of the subfamily Ommastrephinae.
\end{abstract}

Key words: yellow inclusions, histology, ultrastructure

Acuña et al. $2003^{2}$, Sernapesca $2006^{3}$ ). In Coquimbo it is fished by artisanal fishermen, and processed by fishing companies, mainly frozen for the Asiatic and now also

\footnotetext{
${ }^{2}$ Acuña E, Villarroel JC \& M Andrade. 2003. Pesca de jibia Dosidicus gigas (Orbigny, 1835), realizada por la flota artesanal en la IV Región. Informe Final Pesca de Investigación Resolución Subpesca No 1485. Dpto. Biología Marina, Facultad de Ciencias del Mar, Universidad Católica del Norte, Coquimbo, Chile. 37 pp.

${ }^{3}$ Sernapesca, 2006. Servicio Nacional de Pesca, Anuario Estadístico. Ministerio de Economía, Fomento y Reconstrucción, Chile. (http://www.sernapesca.cl) [consultado el 5 de mayo, 2008].
} 
for European markets. When it has been exported to Spain, one questioned the presence of small yellow rice-like inclusions in the mantle muscle.

D. gigas is the largest member of the family Ommastrephidae, and belongs to the most advanced subfamily, the Ommastrephinae (Nigmatullin et al. 2001). The five genera that belong to this subfamily are characterized by the presence of subcutaneous light organs, or photophores, which are often encountered in the tissue of the mantle, head and arms (Roper et al. 1984, Nigmatullin 2007).

Photophores are present in many cephalopods, at different locations, within the mantle, in or by internal organs, in the skin of the mantle, head, tentacles or eyes (Herring 1988). The luminescence emitted by these photophores is either intrinsic, or produced by symbiotic bacteria (Arnold \& Young 1974, Leisman et al. 1980, Herring et al. 1981, Ruby \& McFall-Ngai 1992). The photophores of the squids of the family Ommastrephidae belong to the type of intrinsic light organs (Girsch et al. 1976, Herring et al. 1981). In two members of the subfamily Ommastrephinae, both belonging to the genus Sthenoteuthis, a large dorsal organ, formed by aggregation of many individual light organs which is visible externally, is present. For S. pteropus the individual light organs have been observed with histology and transmission electron microscopy (Clarke 1965, Girsch et al. 1976) and with Alcian Blue in S. oualaniensis (Kishimoto \& Kohno 1992). However, this kind of dorsal photophore has not been observed in D. gigas, which, along with the absence of eye and intestinal photophores in paralarvae and adults (present though in juveniles and subadults) make this species to be considered the least advanced member of the subfamily (Clarke 1965, Clarke \& Paliza 2000, Nigmatullin et al. 2001).

Bioluminescence was reported from D. gigas, as a number of spots of brilliant blue light, located on the head, along the third arm, and as three strong luminous spots on the tips of the arms. This observation was made by chance, when a squid was brought on deck and the light had gone off on board, the luminescence lasting less than 2 minutes (García-Tello 1964). Nesis (1970) described the photophores of $D$. gigas as inconspicuous elongate or oval granules scattered in the muscle of the mantle, the ventral side of the head, and on the outside edge of the $4^{\text {th }}$ pair of arms. The present study analyses the distribution, structure, ultrastructure, and luminescence of the subcutaneous body photophores of $D$. gigas.

\section{Material and methods}

The squids were obtained from artisanal fishermen, who fished for them near the shore off Coquimbo $\left(30^{\circ} \mathrm{S}\right)$ at night and delivered them to the fish processing company, where the squids were headed, skinned, washed, and further processed as required. The samples for this study were taken from the clean mantle on site, at the following dates: 2003/07/07, 2003/07/14, 2003/08/15, 2003/10/07 \& 10, 2003/11/20, 2003/12/13, 2004/02/26, 2004/04/ 6 $\& 24,2005 / 08 / 11,2005 / 10 / 28,2005 / 11 / 02$. Subcutaneous photophores were cut out including part of the surrounding muscle tissue and processed for histology. Whole, isolated ventral mantle photophores were sampled on 2003/07/ 26 and 2004/04/24, and processed for transmission electron microscopy (TEM). No arm photophores were fixed for TEM. Whole squid, arms and tentacles were refrigerated, and taken next morning to the Histology Laboratory of the Universidad Católica del Norte. Here they were examined for the locations of photophores, and sampled for histology. For histology, no difference in the quality of preservation could be detected between samples taken at night, shortly after the capture of the squids, and those taken next day from refrigerated material.

Measurements of the photophores were taken with a digital vernier caliper with a precision of $0.01 \mathrm{~mm}$ from frozen-thawed ventral and dorsal mantle, fins, arms and tentacles.

Bioluminescence was looked at in a dark room from refrigerated squid caught the night before, and also in frozen-thawed squid. The observations were made on dorsal and ventral sides of the mantle, on arms and tentacles, and on the fin, with the skin on. Additionally, the photophores were exposed by peeling off the epidermis and dermis of dorsal and ventral mantle pieces. For stimulating the luminescence, a gentle flow of $2 \%$ $\mathrm{H}_{2} \mathrm{O}_{2}$ (by volume with distilled water or with seawater) was pipetted over the tissue pieces.

For histology the tissue pieces were fixed in Davidson's fixative (Shaw \& Battle 1957) for $24 \mathrm{~h}$, dehydrated in ethanol, cleared in xylene, and embedded in Paraplast. Five micrometer sections were cut and stained with haematoxylin and eosin (H\&E) and Mallory triple stain.

For transmission electron microscopy (TEM) the photophores were fixed in $3 \%$ glutaraldehyde in $0.2 \mathrm{M}$ cacodylate buffer with $1.75 \% \mathrm{NaCl}$, for two hours at room temperature. Tissues were washed three times in $0.2 \mathrm{M}$ cacodylate buffer with $1.75 \% \mathrm{NaCl}$, and post-fixed for one hour either in $1 \% \mathrm{OsO}_{4}$ in the same buffer or in reduced $\mathrm{OsO}_{4}(1: 1$ mixture of $3 \%$ aqueous potassium ferrocyanide and 2\% osmium tetroxide). After washing three times with buffer, they were rinsed twice in distilled water, stained for 15 min with $2 \%$ aqueous uranyl acetate, dehydrated in ethanol, washed in acetone, and embedded in Epon 812. Semi-thin sections, $1 \mu \mathrm{m}$ thick, were cut on 


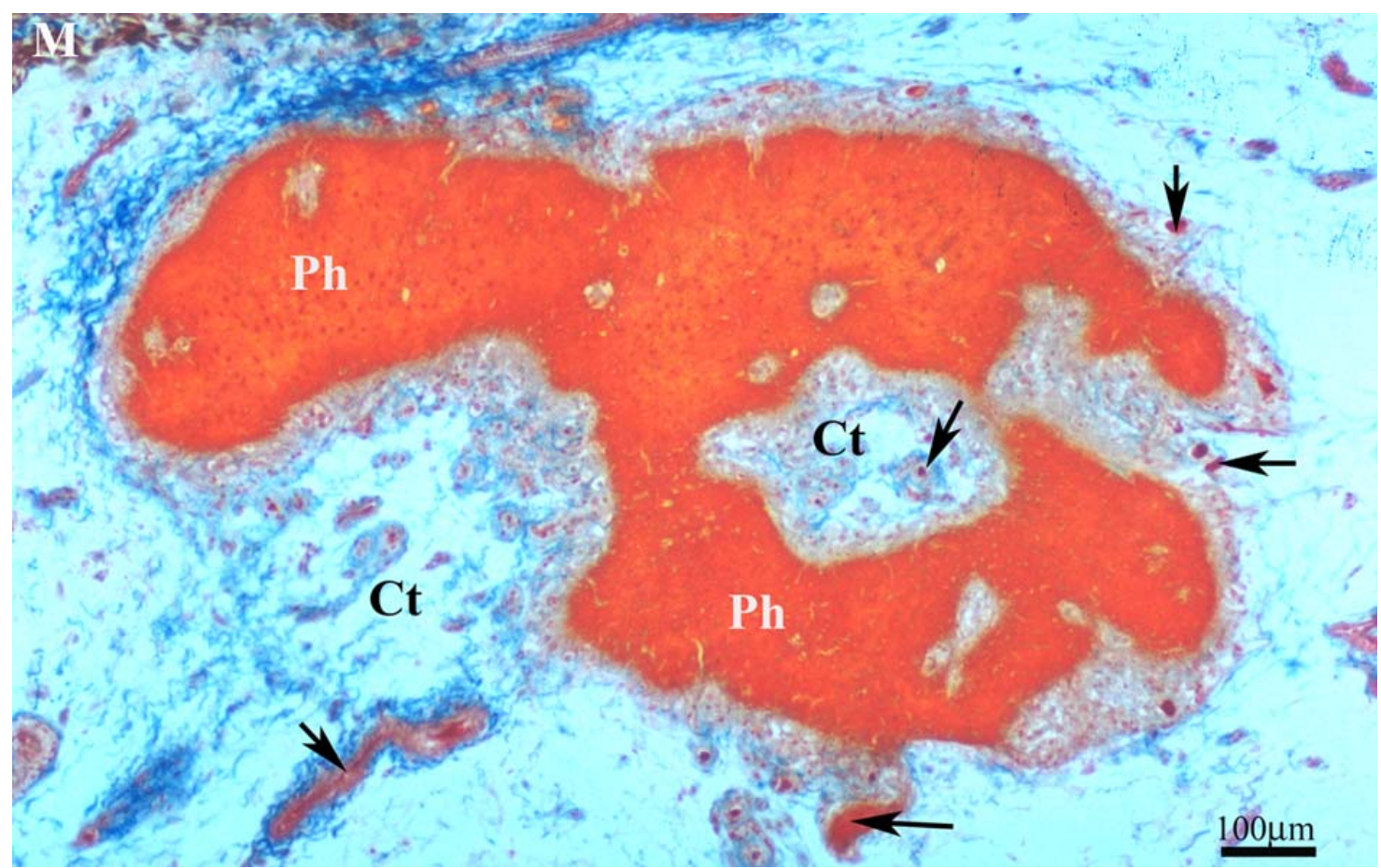

Figure 1

Histological section of a $D$. gigas mantle photophore stained with Mallory triple stain. The photogenic tissue (Ph) stains orange, the connective tissue $(\mathrm{Ct})$ surrounds it, and intrudes into it. The hemocyanin inside the numerous blood vessels (arrows) stains orange or red, the collagen stains blue. On the left top corner some mantle muscle tissue can be seen (M)

Corte histológico de un fotóforo del manto de D. gigas teñido con tinción tricrómica de Mallory. El tejido fotogenerador (Ph) se tiñe color naranja, el tejido conectivo $(\mathrm{Ct})$ lo rodea y penetra en él. La hemocianina dentro de los numerosos vasos sanguíneos (flechas) se tiñe color naranja o rojo, el colágeno se tiñe color azul. En la esquina superior izquierda se observa una pequeña porción de tejido muscular del manto (M)

a Reichert Ultracut S microtome, and stained with toluidine blue. Ninety $\mathrm{nm}$ thin sections were cut with a diamond knife, collected on copper grids, and stained with aqueous uranyl acetate and lead citrate. The sections were viewed with a Zeiss EM-9 electron microscope at $50 \mathrm{kV}$, and photographs were taken.

For scanning electron microscopy (SEM), sections from selected wax blocks were cut at 12 to $15 \mu \mathrm{m}$, and mounted on coverslips. Sections were de-waxed in three changes of xylene, passed through three changes of $100 \%$ ethanol and critical point dried using $\mathrm{CO}_{2}$. Samples were mounted on stubs, and ion sputtered with gold. The sections were viewed and photographed using a JEOL TS 300 microscope (Lohrmann et al. 2002).

\section{Results}

\section{Morphology and histology}

Subcutaneous photophores are small, elongate bodies, located under the dermis, embedded in the mantle muscle.
They are a very light yellow colour when fresh becoming yellow when refrigerated or frozen. Histologically they were composed of the photogenic tissue, which showed a lobular, irregular outline, and stained orange with Mallory triple stain, surrounded by a highly vacuolated and irrigated connective tissue which also intruded into it. The collagen fibrils of the connective tissue stained blue and the hemocyanin in the interior of the blood vessels stained orange or red with Mallory triple stain (Fig. 1). Cellular and vascular elements of this tissue were highly concentrated around the photogenic tissue, without forming a true capsule around it. The connective tissue which lies between the photophore and the mantle muscle resembled damaged tissue when observed in $5 \mu \mathrm{m}$ histological sections (Figs. 1 and 2a). However, on 12 $\mu \mathrm{m}$ thick sections viewed with SEM it was realized that it corresponded to connective tissue with many big vacuoles (Fig. 2b). On arms and tentacles photophores were either on the outer edge, especially on arm IV, or buried deeply, in close association with the axial nerve 

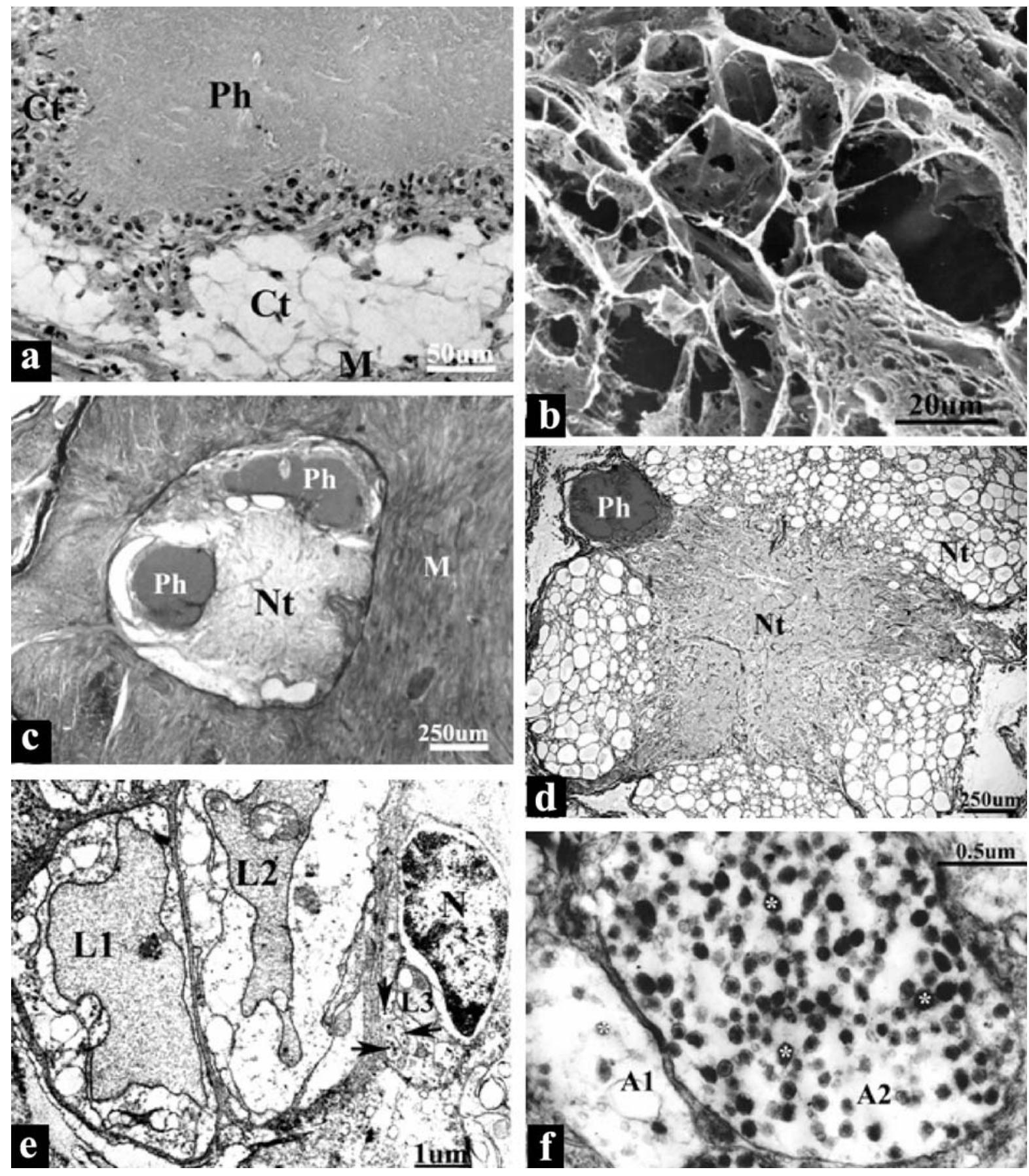

Figure 2

a. D. gigas mantle photophore in histological section. The photogenic tissue $(\mathrm{Ph})$ is surrounded by connective tissue $(\mathrm{Ct})$, which has its cellular and vascular elements more concentrated around and in the photogenic tissue. The connective tissue that lies between the photogenic tissue $(\mathrm{Ph})$ and the muscle tissue $(\mathrm{M})$ seems to be damaged. Stain: $\mathrm{H} \& \mathrm{E}$

b. Scanning electron microscopy (SEM) of a $12 \mu \mathrm{m}$ thick histological section of connective tissue. What looks like damaged tissue in a $5 \mu \mathrm{m}$ thick section as shown in $2 \mathrm{a}$, is revealed as a connective tissue with many big vacuoles when viewed with SEM on a $12 \mu \mathrm{m}$ thick section

c. Transverse histological section through the axial nerve of arm III, close to the tip. Two photophores (Ph) are located in close association with the nervous tissue (Nt). M: muscle tissue. Stain: Mallory triple stain 
cont. Fig. 2

d. Transverse histological section through the axial nerve of arm IV. A photophore (Ph) is located in close association with the nervous tissue (Nt). Stain: Mallory triple stain

e. Transmission electron microscopy (TEM) of three small blood vessels. L1 \& L2: lumen of blood vessels $N^{\circ} 1 \& N^{\circ} 2$ respectively, containing hemocyanin showing a paracrystalline pattern. L3: endotelial cell of blood vessel $N^{\circ} 3$, N: nucleus of endothelial cell; arrows point to two sectioned axons

f. High power TEM image of transverse sections of axons from Fig. 2e. A1: axon 1, A2: axon 2. $\left({ }^{*}\right)$ : neurosecretory vesicles

a. Fotóforo del manto de D. gigas en corte histológico. El tejido fotogenerador $(\mathrm{Ph})$ se encuentra rodeado por tejido conectivo $(\mathrm{Ct})$, cuyos elementos celulares y vasculares están más concentrados en la periferia y en el interior del tejido fotogenerador. El tejido conectivo que se encuentra entre el tejido fotogenerador y el tejido muscular $(\mathrm{M})$ parece estar dañado. Tinción: $\mathrm{H} \& \mathrm{E}$

b. Corte histológico de $12 \mu \mathrm{m}$ de grosor preparado para su observación en el microscopio electrónico de barrido (MEB). Lo que en cortes delgados $(5 \mu \mathrm{m})$, como el que se muestra en $2 \mathrm{a}$, parece ser un tejido dañado, se revela como un tejido conectivo con muchas vacuolas de gran tamaño, al observar un corte grueso $(12 \mu \mathrm{m})$ con el MEB

c. Corte histológico transversal a través del nervio axial del brazo III, cerca del extremo distal del brazo. Dos fotóforos (Ph) se encuentran en íntima asociación con el tejido nervioso (Nt). M: tejido muscular. Tinción: Tricrómico de Mallory

d. Corte histológico transversal a través de nervio axial del brazo IV. Se observa un fotóforo en íntima asociación con el tejido nervioso (Nt). Tinción: Tricrómico de Mallory

e. Tres pequeños vasos sanguíneos vistos con microscopía electrónica de transmisión (MET). L1 y L2 corresponden al lumen de los vasos L1 y L2 respectivamente, conteniendo hemocianina, que muestra un arreglo paracristalino. L3: célula endotelial de vaso $\mathrm{N}^{\circ} 3$; $\mathrm{N}$ : núcleo de célula endotelial; flechas indican dos axones en corte transversal

f. Imagen aumentada de los axones cortados transversalmente de la Fig. 2e. A1: axon 1; A2: axon 2. (*): Vesículas neurosecretoras

cord (Figs. 2c and 2d). Figure 2d shows a photophore from a section in the middle region of arm IV; figure $2 \mathrm{c}$ shows two photophores from a section very close to the tip of arm III.

\section{Ultrastructure}

Only mantle photophores were processed for transmission electron microscope (TEM). In the vacuolated tissue that surrounds and intrudes into the photogenic tissue numerous small blood vessels could be observed, (Figs. $2 \mathrm{e}$ and $3 \mathrm{~b}$ ), some of them in association with nerve elements (Figs. 2e and 2f). The latter were never seen close to the photogenic tissue. In addition to the small blood vessels, numerous capillaries were seen. They could be recognized by their basement membrane, and the hemocyanin, which shows a paracrystalline pattern (Figs. 2e, 3a and 3d). Near to the capillaries bundles of myofilaments were observed, some in longitudinal and some in transverse section (Fig. 3a). The photogenic tissue itself was electron dense, homogeneously finely granular (Figs. 3a, 3b and 3c), close to capillaries (Fig. 3a) and adjacent to cells with numerous mitochondria (Figs. 3c and $3 d)$. The tissues shown in figures $3 b, 3 c$ and $3 d$ were processed with reduced $\mathrm{OsO}_{4}$, which enhances the membranes. The plasma membrane of a vacuolated tissue cell filled with many mitochondria could be observed (Fig. $3 \mathrm{c}$ ); figure $3 \mathrm{~d}$ shows a high magnification image of mitochondria, where the internal membranes can clearly be seen. The photogenic tissue did not show any membranes, it rather seemed to be filling the spaces between the cells of the vacuolated tissue.

\section{Photophore distribution and size structure}

Photophores were observed all over the squid on tentacles, arms, head, mantle and the fin. However, the abundance, size and orientation of the photophores varied depending on their location. On the ventral side of the mantle, they were oriented perpendicular to the long axis of the squid, increasing in number, and also in size, from cephalic to caudal. Table 1 summarizes the sizes of photophores from dorsal and ventral sides of the mantle, fins, and from each arm and tentacle. On the ventral and dorsal surfaces of the head a few photophores were seen, similar in size to the ventral mantle photophores. The size of photophores that run along the axial nerve is given separately from those that run on the outer arms' edge. They are scarce and very small (mean length from 0.1 to $0.25 \mathrm{~mm}$ ), and their long axis is parallel to the long axis of arms and tentacles. However, arm IV has more and longer photophores running along the axial nerve than the other arms; the length of these photophores was highly variable, hence the high standard deviation. Here the longest photophores of the whole squid were observed measuring up to $80 \mathrm{~mm}$ in length (mean length of $3.6 \mathrm{~mm}$ ). They were located half way from the base of the arm. Additionally, an almost continuous row of photophores was lined along the outer edge of arm IV, though smaller with a mean length of $1.3 \mathrm{~mm}$. The width, however, was quite stable, ranging from 0.11 to $0.17 \mathrm{~mm}$ in arm and tentacle photophores (Table 1). All arms had 3 to 6 


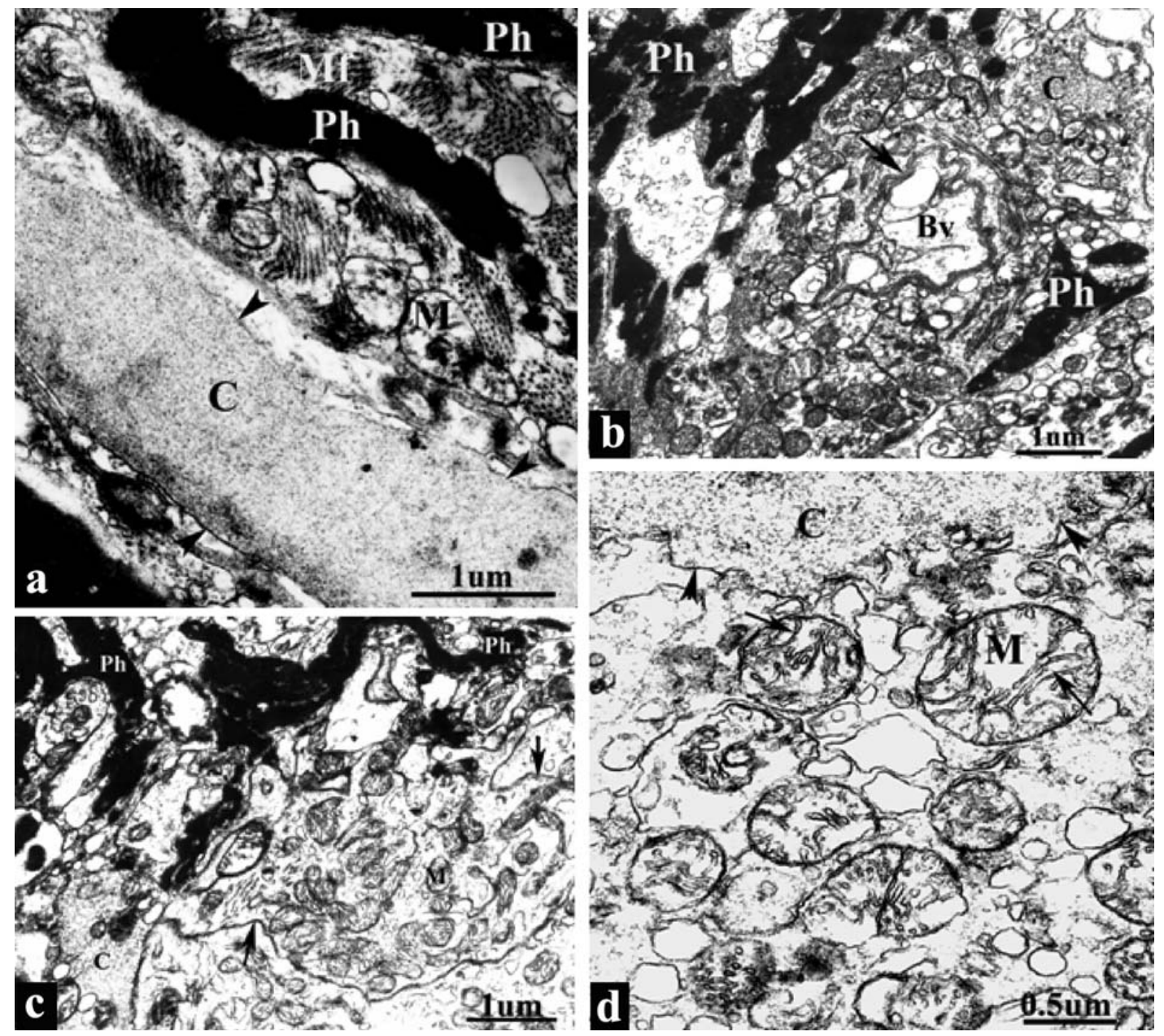

Figure 3

Transmission electron microscopy (TEM) of D. gigas photophores. The tissues observed in Fig. 3a were processed using buffered $\mathrm{OsO}_{4}$. Reduced $\mathrm{OsO}_{4}$, which enhances the membranes, was used in the processing of the tissues observed in Figs. 3b, 3c and 3d

a. A capillary (C) in longitudinal section, containing hemocyanin. Myofilament bundles (Mf) in longitudinal and transverse section. M: Mitochondria; Ph: photogenic tissue; arrowheads: basement membrane of capillary

b. Photogenic tissue (Ph) close to blood vessel (Bv); arrow: basement membrane of the blood vessel; C: capillary

c. Photogenic tissue $(\mathrm{Ph})$ and cell with numerous mitochondria (M). Arrows point to the plasma membrane of the cell with mitochondria

d. Higher power TEM image of some mitochondria (M), arrows point to mitochondrial cristae. C: capillary; arrowheads: basement membrane of capillary. The contents of the capillary corresponds to hemocyanin

Microscopía electrónica de transmisión (MET) de fotóforos de D. gigas. Los tejidos observados en la Fig. 3a fueron procesados usando $\mathrm{OsO}_{4}$ tamponado. Para el procesamiento de los tejidos de las Figs. 3b, 3c y 3d, se utilizó $\mathrm{OsO}_{4}$ reducido, que realza las membranas

a. Capilar (C) en corte longitudinal, conteniendo hemocianina. Haces de miofilamentos (Mf) cortados longitudinal y transversalmente. M: Mitocondria; Ph: tejido fotogenerador; puntas de flecha indican membrana basal del capilar

b. Tejido fotogenerador $(\mathrm{Ph})$ cerca de vaso sanguíneo (Bv); flecha: membrana basal del vaso sanguíneo; C: capilar sanguíneo c. Tejido fotogenerador $(\mathrm{Ph})$ asociado a célula con muchas mitocondrias $(\mathrm{M})$. Las flechas apuntan a la membrana plasmática de la célula con mitocondrias

d. Algunas mitocondrias (M) observadas con mayor aumento, las flechas indican las crestas mitocondriales. C: capilar; puntas de flecha: membrana basal de capilar. El contenido del capilar corresponde a hemocianina 
Table 1

Size of photophores in Dosidicus gigas

Tamaño de los fotóforos de Dosidicus gigas

\begin{tabular}{lccccc}
\hline Photophore location & \multicolumn{2}{c}{ Length $(\mathrm{mm})$} & \multicolumn{2}{c}{ Width $(\mathrm{mm})$} & $\mathrm{n}$ \\
& Mean & SD & Mean & SD & \\
\hline Dorsal mantle & 1.32 & 0.356 & 0.70 & 0.160 & 46 \\
Ventral mantle & 2.53 & 0.010 & 1.20 & 0.338 & 94 \\
Fin (middle) & 0.33 & 0.456 & 1.13 & 0.034 & 66 \\
Fin (rim) & 0.13 & 0.091 & 0.07 & 0.017 & 52 \\
Arm I (axial nerve) & 0.20 & 0.094 & 0.14 & 0.049 & 61 \\
Arm I (edge) & 0.14 & 0.048 & 0.11 & 0.034 & 17 \\
Arm II (axial nerve) & 0.24 & 0.131 & 0.16 & 0.056 & 66 \\
Arm II (edge) & 0.16 & 0.067 & 0.13 & 0.044 & 52 \\
Arm III (axial nerve) & 0.25 & 0.156 & 0.15 & 0.058 & 74 \\
Arm III (edge) & 0.20 & 0.075 & 0.15 & 0.054 & 52 \\
Arm IV (axial nerve) & 3.60 & 11.210 & 0.16 & 0.054 & 183 \\
Arm IV (edge) & 1.30 & 3.419 & 0.17 & 0.047 & 128 \\
Tentacle (axial nerve) & 0.20 & 0.080 & 0.14 & 0.053 & 130 \\
Tentacle (edge) & 0.18 & 0.085 & 0.15 & 0.050 & 102 \\
\hline
\end{tabular}

Measurements of the length and width of the photophores of dorsal and ventral mantle, fin, arms and tentacles. In arms and tentacles the photophores that run along the axial nerve were measured separately from those that are located on the outer edge. For tentacles, a long photophore $(1.9 \mathrm{~mm})$ located on the tip on the outer edge was not included for calculating the mean length. $\mathrm{n}$ : number of photophores measured; SD: standard deviation

photophores concentrated at 5 to $6 \mathrm{~cm}$ from the tip. On the tentacles, photophores of small size $(0.2 \mathrm{~mm}$ mean length) were observed along the axial nerve, and along the outer edge. However, there was a long photophore (1.9 mm long) located at the outer edge $1-2 \mathrm{~cm}$ from the tip. On the fin, small photophores were buried in the middle region under or over a median sheath of collagen, where the muscle bundles are inserted. On the fin rim very small, superficial photophores were observed.

\section{Bioluminescence}

Bioluminescence was observed in a dark room from refrigerated squid caught the night before, and also in frozen-thawed squid. Once the observer's eyes adapted to the darkness, a weak, yellow-greenish luminescence was visible from exposed photophores. It was strongly enhanced pouring $2 \% \mathrm{H}_{2} \mathrm{O}_{2}$ over the tissue, no matter whether it had been diluted with seawater or distilled water, the latter having a faster effect (almost instantaneous). The luminescence from fresh photophores was stronger than from frozen-thawed photophores. Nevertheless, mantle pieces that had been frozen for 3 months would still emit luminescence. The photophores from dorsal mantle gave intermittent flashes of light of 1or $2 \mathrm{~s}$ duration. The ventral photophores also gave flashes of light, but these were longer lasting, and did not change so quickly. The isolated arm IV string of photophores from the outer edge gave a strong, steady luminescence.

Whole arms, tentacles, dorsal and ventral mantle and fin with skin were also stimulated with $2 \% \mathrm{H}_{2} \mathrm{O}_{2}$ in the dark room. The luminescence took 2 or 3 min longer to become visible than in exposed photophores, however, it was the same colour as in them. It was also useful for finding photophores without skinning the squid. The whole dorsal fin rim was illuminated, as well as arm and tentacle tips, which were then processed for histology. Histologically, the photophores from mantle, arms, tentacles and fins showed a common structure.

\section{Discussion}

The results of this study show that the subcutaneous photophore of $D$. gigas is very basic, formed by photogenic tissue surrounded by a vacuolar connective tissue, with numerous blood vessels. This vacuolar tissue intrudes into the photogenic tissue, providing it with many capillaries. The photophore from $S$. pteropus shows a very similar structure, the only difference being that in $S$. pteropus an additional layer of connective tissue lines the photogenic tissue (Girsch et al. 1976). Clarke (1965), also for S. pteropus, described a 'white tissue', modified 
as a reflector, located immediately underneath the photophores of the dorsal organ. This was observed in a transverse section of the mantle with the dorsal organ. This 'white tissue' stained blue with Mallory, probably corresponding to collagen, and was oriented parallel to the skin surface. This layer was not mentioned by Girsch et al. (1976) who studied photophores that had been isolated from the dorsal organ, so they could not have observed it. In this study nothing but muscle fibres was observed around the photophores from all locations, nothing like a reflector could be discerned. Okada (1968) described the structure of the subcutaneous photophores of Eucleoteuthis luminosa and Hyaloteuthis pelagica. Histologically the photogenic tissue is similar to what is encountered in D. gigas and in S. pteropus. However, there are two additional layers, a reflective muscle layer (similar to the one described by Clarke (1965) for $S$. pteropus) underneath the photogenic body, and a fan shaped light dispersing layer composed of connective tissue located under the dermis. The other species belonging to the subfamily Ommastrephinae is Ommastrephes bartramii. It only has photophores as an adult, and in this species they are restricted to small, irregular light organs embedded in the ventral mantle and ventral head (Young 1972, Roper et al. 1984, Dunning 1998). No information on the structure of the photophores could be found, and to our knowledge no histology has been undertaken.

The ultrastructure of the photophore of D. gigas, as evidenced by transmission electron microscopy (TEM) is comparable to the photophore of the other species studied with TEM, S. pteropus, which is also very similar at the histological level (Girsch et al. 1976). Capillaries are very numerous in the vacuolar connective tissue, and they are in direct contact with the photogenic tissue. Barber \& Graziadei (1965) described the fine structure of four types of cephalopod small blood vessels. These consist of pericytes, a basement membrane, and one or few endothelial cells. Those seen in D. gigas are very similar to two of them, type 2 and type 4 vessels. Some blood vessels seem to consist of the basement membrane only; as endothelial cells are sparse, and sometimes only one endothelial cell is present, there are vast extensions of apparently naked basement membrane, especially when the capillary is filled with haemolymph. The same intimate association between photogenic tissue and capillaries seen with TEM in D. gigas was observed in S. pteropus (Girsch et al. 1976), and in the enoploteuthid squid Pterygioteuthis microlampas (Arnold \& Young 1974).

Can the ultrastructure of the photophore answer how the light production is controlled? In D. gigas, some axons were observed in one of the sections, closely associated with blood vessels. They were probably not very numerous, since they were not observed in other sections. It is also possible that in such a thin section as is required for TEM they could have been missed, as it discussed by Girsch et al. (1976), who did not see any nerve elements in their TEM sections. However, these axons were in close proximity to the blood vessels, not to the photogenic tissue. So it is possible, as suggested by Girsch et al. (1976) that the function of the light organs could be indirectly controlled through the blood supply. The photogenic tissue requires oxygen for light emission, which is provided by the hemocyanin in the haemolymph. On the other hand, the presence of cells with numerous mitochondria also indicates the production of large amounts of ATP. Similar 'mitochondrial cells', have been described by Arnold \& Young (1974) as forming part of the photogenic organ of the squid Pterygiotheuthis microlampas. The nerve elements observed in close association with blood vessels in D. gigas might control the perivascular myofibrils, modifying the lumina of the blood vessels, and hence the haemolymph supply. Unfortunately no TEM samples were prepared from those arm or tentacle photophores that run close to the axial nerve. At light microscopy level, they looked exactly like the mantle light organs, with a high blood supply from the vacuolated connective tissue. However, it would have been interesting to see if there is a direct connection between these axons and the photophores.

Subcutaneous photophores are difficult to see in fresh specimens, partly because of their small size, but mainly due to their colour, which is very similar to the colour of muscle tissue. Kishimoto \& Kohno (1992) used a technique that gave good results for counting and measuring photophores in $S$. oualaniensis. It consisted of staining with alcian blue and clearing with $\mathrm{KOH}$, making the muscle tissue translucent, and the blue photophores visible. However, this technique would be very difficult to be used in D. gigas due to their big size, at an average mantle length (ML) of around 65 to $72 \mathrm{~cm}$. The biggest specimen of $S$. oualaniensis studied by Kishimoto \& Kohno (1992) had a ML of $15.4 \mathrm{~cm}$. Roper (1963) found that squid muscle that had been fixed in formalin for several years, and sometimes kept in 70\% ethanol, became translucent, while the photophores kept their yellow colour. Again, this is also difficult to do with very large specimens. In this study it was found that freezing the squid muscle darkens the colour of the photophores, from the fresh light cream-yellow, to yellow, which made them easier to see. The other means of finding photophores was pouring $\mathrm{H}_{2} \mathrm{O}_{2}$ on whole parts of the squid, and afterwards dissecting the portions which glowed in the dark, either for measuring them, or for processing them 
for histology. Each of these methods has contributed to the knowledge of the distribution of the subcutaneous photophores of squids of the subfamily Ommastrephinae. Roper (1963) detected them in formalin fixed tissues of S. pteropus in the ventral mantle muscle, on the dorsolateral part of the head, along the outer edge of the ventral $\left(4^{\text {th }}\right)$ arm pair, as well as on the other arms and the tentacles. However, he did not find any dorsal photophores, except for a few scattered ones on the region near to the fins. He stated that the location and distribution of the subcutaneous photophores of S. pteropus is similar in S. oualaniensis and in D. gigas. However, in this study dorsal mantle photophores were found, smaller though than the ventral ones and at first they had not been detected. Kishimoto \& Kohno (1992) also observed dorsal subcutaneous photophores on the mantle of $S$. oualaniensis and on both ventral and dorsal mantle of one specimen of $O$. bartramii stained with alcian blue. On this latter species, Young (1972) did not see any dorsal photophores in one small $21 \mathrm{~cm}$ ML specimen. However, from the same specimen he described a long band of photogenic tissue from the base of the ventral arm almost to the tip. Roper (1963) also described a row of closely packed photophores along the outer edge of the arm IV in S. pteropus, the same was observed in this study for $D$. gigas. Photophores on the outer edge of arm IV had also been reported for this species by Nesis (1970), being the same for males and females. García-Tello (1964) described the luminescence, when a specimen of D. gigas fell on board in complete darkness, along the third arm, on the ventral side, around the suckers, and also three light emitting points on the tips of arms and tentacles. As this only lasted a few minutes, and it was dark, he might have confused the arms. The arms other than the fourth arm and the tentacles have very few photophores, except for the tips, where they are more numerous. With histology small photophores were detected, sparsely distributed along the axial nerve in arms and tentacles in D. gigas; the same was described in E. luminosa by Okada (1968). On other members of the subfamily no histology has been performed on arms or tentacles; they might also have these photophores running along the axial nerve.

The length of the photophores was highly variable, longer photophores might be formed by fusion or a very tight, lengthwise, apposition of them. The width (or diameter), however, was quite stable, and may be a more reliable measure of the size. Comparing the size of the photophores of $D$. gigas with the size of them in other members of this subfamily, it can be said that the dorsal mantle ones are similar in size to those from $S$. oualaniensis measured on a $15.4 \mathrm{~cm}$ ML specimen (Kishimoto \& Kohno 1992). In the same species the largest specimen had ventral mantle photophores measuring $1.8 \times 0.8 \mathrm{~mm}$. The authors state that the number as well as the size of the photophores increase with increasing mantle length. Roper (1963) measured the diameter of photophores of $S$. pteropus of three sizes, 8 $\mathrm{cm}, 11.6$, and $27.5 \mathrm{~cm}$ ML. The photophores of the latter were 0.8 to $2.7 \mathrm{~mm}$ in diameter. This is similar to the size of the mantle photophores of D. gigas. He also found that smaller specimens had smaller photophores. In this study it was not possible to have access to any small $D$. gigas although it may be possible to make measurements of small specimens in the future.

Light emission of $S$. pteropus has been described as bright blue light flashes (Girsch et al. 1976), or pale blue light (Roper 1963), and for D. gigas as brilliant blue (García-Tello 1964). It was not possible to observe any live $D$. gigas, the isolated photophores viewed in a dark room, enhanced or not with $\mathrm{H}_{2} \mathrm{O}_{2}$ showed a yellowgreenish colour, no blue colour could be observed.

\section{Conclusion}

Dosidicus gigas has the simplest possible subcutaneous photophore structure, formed by photogenic tissue and vacuolated, highly vascular connective tissue surrounding and penetrating it. So it may have the simplest light organ of the subfamily Ommastrephinae, which would be in accordance with this species being the least advanced member of the subfamily. However, the structure of the photophores of $O$. bartramii is still to be studied, before a conclusive statement on subcutaneous photophore structure in this subfamily can be made.

\section{Acknowledgments}

My gratitude to Héctor Pujado from Pesquera San José for his help in providing and sampling the squids. Many thanks to Ana Luisa Valdivia for superb histology and to Fidel Vargas for his skillful assistance in TEM. I wish to thank Dr. Richard Young for his orientation when I started looking at what I thought was an infection, and very special thanks to Dr. Chingis Nigmatullin for his expert, kind and patient help with the manuscript, improving it notoriously. And last but not least, I am very grateful to two anonymous reviewers whose most valuable comments shaped the final version of this manuscript.

\section{Literature cited}

Arnold JM \& RE Young. 1974. Ultrastructure of a cephalopod photophore. I. Structure of the photogenic tissue. The Biological Bulletin 147(3): 507-521.

Barber VC \& P Graziadei. 1965. The fine structure of cephalopod blood vessels. I: some smaller peripheral 
vessels. Zeitschrift für Zellforschung und Mikroskopische Anatomie 66: 765-781.

Clarke MR. 1965. Large light organs on the dorsal surfaces of the squid Ommastrephes pteropus, Symplectoteuthis oualaniensis and Dosidicus gigas. Proceedings of the Malacological Society of London 36: 319-321.

Clarke R \& O Paliza. 2000. The Humboldt Current squid Dosidicus gigas (Orbigny, 1835). Revista de Biología Marina y Oceanografía 35(1): 1-39.

Dunning MC. 1998. A review of the systematics, distribution, and biology of the arrow squid genera Ommastrephes Orbigny, 1835, Sthenoteuthis Verril, 1880, and Ornithoteuthis Okada, 1927 (Cephalopoda: Ommastrephidae). In: Voss NA, M Vecchione, RB Toll \& MJ Sweeney (eds), Systematics and Biogeography of Cephalopods. Smithsonian Contributions to Zoology 586(2): 425-433.

Fernández F \& JA Vásquez. 1995. The jumbo flying squid Dosidicus gigas (Orbigny, 1835) in Chile: Analysis of an ephemeral fishery. Estudios Oceanológicos 14: 17-21.

García-Tello P. 1964. Nota preliminar sobre una observación de bioluminiscencia en Dosidicus gigas (d'Orb) Cephalopoda. Boletín de la Universidad de Chile 46: 2 728.

Girsch SJ, PJ Herring \& F McCapra. 1976. Structure and preliminary biochemical characterization of the bioluminescent system of Ommastrephes pteropus (Steenstrup) (Mollusca: Cephalopoda). Journal of the Marine Biological Association of the United Kingdom 56: 707-722.

Herring PJ. 1988. Luminescent organs. In: Trueman ER \& MR Clarke (eds), The Mollusca 11: Form and function, pp. 449-489. Academic Press, San Diego.

Herring PJ, MR Clarke, S. v. Boletzky \& KP Ryan. 1981. The light organs of Sepiola atlantica and Spirula spirula (Mollusca:Cephalopoda): bacterial and intrinsic systems in the order Sepiodea. Journal of the Marine Biological Association of the United Kingdom 61: 901-916.

Kishimoto H \& H Kohno. 1992. Development of the luminous organ in the Purpleback Flying squid, Stenoteuthis oualaniensis, as shown by alcian blue stain techniques. Bulletin of the Institute of Oceanic Research \& Development 13: 71-83.
Leisman G, DH Cohn \& KH Nealson. 1980. Bacterial origin of luminescence in marine animals. Science 208: 12711273.

Lohrmann KB, AR Brand \& SW Feist. 2002. Comparison of the parasites and pathogens present in a cultivated and in a wild population of scallops (Argopecten purpuratus Lamarck, 1819) in Tongoy Bay, Chile. Journal of Shellfish Research 21(2): 557-561.

Nesis KN. 1970. The biology of the giant squid Dosidicus gigas. Oceanology 10: 108-118. (English translation).

Nigmatullin ChM. 2007. Brief review on evolutionary and ecological aspects of biology of squids family Ommastrephidae (Cephalopoda: Teuthida). Scientific Proceedings of Kazan State University, Series: Natural Sciences 149(3): 182-193. (In Russian with English abstract).

Nigmatullin ChM, KN Nesis \& AI Arkhipkin. 2001. A review of the biology of the jumbo squid Dosidicus gigas (Cephalopoda: Ommastrephidae). Fisheries Research 54: 9-19.

Okada YK. 1968. Study of luminous Cephalopoda I. Luminous squids belonging to the Ommastrephidae. Science Report of the Yokosuka City Museum 14: 88-94.

Roper CFE. 1963. Observations on bioluminescence in Ommastrephes pteropus (Steenstrup, 1855), with notes on its occurrence in the family Ommastrephidae (Mollusca: Cephalopoda). Bulletin of Marine Science 13: 343-353.

Roper CFE, MJ Sweeney \& CE Nauen. 1984. FAO Species Catalogue. Vol. 3. Cephalopods of the World. An annotated and illustrated catalogue of species of interest to fisheries. FAO Fisheries Synopsis 125 (3): 1-277.

Ruby EG \& MJ McFall-Ngai. 1992. A squid that glows in the night: development of an animal-bacterial mutualism. Journal of Bacteriology 174(15): 4865-4870.

Schmiede P \& E Acuña. 1992. Regreso de las jibias (Dosidicus gigas) a Coquimbo. Revista Chilena de Historia Natural 65: 389-390.

Shaw BL \& HI Battle. 1957. The gross microscopic anatomy of the digestive tract of the oyster Crassostrea virginica (Gmelin). Canadian Journal of Zoology 35: 325-347. 